\title{
Effects of the Voltage and Pressure on the Carburizing of Martensitic Stainless Steel in Pulsed DC Glow Discharge
}

\author{
Cristiano J. Scheuer ${ }^{a, b}$ (1), Rodrigo P. Cardoss ${ }^{a, c}$ (1), Márcio Mafra ${ }^{a, d}$ (D), Silvio F. Brunatto ${ }^{a *}$ (]) \\ ${ }^{a}$ Universidade Federal do Paraná (UFPR), Departamento de Engenharia Mecânica (DEMEC), \\ Grupo de Tecnologia de Fabricação Assistida por Plasma e Metalurgia do Pó, Curitiba, PR, Brasil. \\ ${ }^{b}$ Universidade Federal de Santa Maria (UFSM), Departamento de Engenharia Mecânica (DEM), \\ Santa Maria, RS, Brasil. \\ ${ }^{c}$ Universidade Federal de Santa Catarina (UFSC), Departamento de Engenharia Mecânica (EMC), \\ Florianópolis, SC, Brasil. \\ ${ }^{d}$ Universidade Tecnológica Federal do Paraná (UTFPR), Departamento Acadêmico \\ de Mecânica (DAMEC), Curitiba, PR, Brasil.
}

Received: March 28, 2021; Revised: August 17, 2021; Accepted: August 19, 2021.

In the present work, the influence of the pulse voltage and pressure on the treatment glow discharge characteristics and consequently on the surface properties obtained for low temperature plasma carburized AISI 420 martensitic stainless steel was investigated. Two distinct sets of samples were carburized at $450^{\circ} \mathrm{C}$, for $8 \mathrm{~h}$, one aiming to study the applied pulse voltage effects, which was varied for 500,600 and $700 \mathrm{~V}$, at a fixed pressure of $400 \mathrm{~Pa}$, and the other aiming to study the pressure effects, which was varied for 200,400 , and $800 \mathrm{~Pa}$, at a fixed pulse voltage of $700 \mathrm{~V}$. Treated samples were characterized by means of confocal laser scanning microscopy (CLSM), X-ray diffraction (XRD) analysis, microhardness and roughness measurements. The glow discharge (plasma) was characterized by optical emission spectroscopy (OES) and current measurements. Results show that the edge effect, surface roughness, hardness and outer layer growth kinetics are dependent on the studied plasma parameters. OES analyses showed that the pulse voltage parameter does not promote significant changes on the plasma chemistry, but confirmed that the molecular $\mathrm{H}_{2}$ gas dissociation rate tends to be significantly affected by the pressure parameter giving important support for the results obtained here.

Keywords: AISI 420 martensitic stainless steel, low-temperature pulsed dc plasma carburizing, pressure and pulse voltage parameters, optical emission spectroscopy, glow discharge (plasma) diagnostic.

\section{Introduction}

Martensitic stainless steels (MSSs) are widely used in different industrial fields comprising the manufacturing of surgical instruments ${ }^{1-3}$, forming tools ${ }^{3-5}$, hydraulic system elements $^{3,5,6}$, structural and machine parts ${ }^{3,5,7}$, dairy and food apparatus ${ }^{1,4,7}$, petrochemical $^{8}$, and mining industry ${ }^{9}$ components. They present wide application field due to their relatively high mechanical strength and moderate corrosion resistance ${ }^{10}$. Nevertheless, application limitations are mainly found on conditions where high wear and corrosion resistances are required, in addition to adequate mechanical properties ${ }^{11}$.

Low temperature plasma carburizing (LTPC) treatment is a valuable surface engineering technique aiming to improve the MSSs corrosion performance ${ }^{12}$ and their tribological response for specific systems ${ }^{13,14}$. LTPC means that the treatment temperature is high enough to promote the carbon interstitial diffusion, but low enough to avoid the chromium substitutional diffusion, resulting in paraequilibrium condition ${ }^{15}$. In the practical case, it occurs for treatment temperatures equal or lower than $450{ }^{\circ} \mathrm{C}$ and for times relatively short ${ }^{12-14,16}$. The obtained MSSs LTPC surfaces

*e-mail address: brunatto@ufpr.br are usually constituted of cementite $\left(\mathrm{Fe}_{3} \mathrm{C}\right)$ and $\mathrm{C}$-expanded martensite $\left(\alpha^{\prime}\right)$ phases ${ }^{17}$, conferring significant strengthening as well as good corrosion resistance ${ }^{12}$ for the treated surface. Differently, at high-temperatures that for MSSs carburizing means to be higher than $450^{\circ} \mathrm{C}$ the formation of $\mathrm{M}_{23} \mathrm{C}_{6}, \mathrm{M}_{6} \mathrm{C}$, $\mathrm{M}_{7} \mathrm{C}_{3}$ phases provokes sensitization of the steel ${ }^{18}$.

Concerning the influence of the processing parameters studied here, the literature is rich for austenitic stainless steels (ASSs) plasma nitriding ${ }^{19-29}$, but very poor for MSSs, being mainly focused on treated surface characteristics of different materials, through different processes ${ }^{30-40}$. It is to be noted that almost nothing has been published aiming to study such effects on the MSSs LTPC. For ASSs, controversial results by comparing ref ${ }^{19,20}$. and $\mathrm{ref}^{21-24}$. have been reported for the pressure effects on the layer hardness and thickness, but all these authors agree very well that the pressure increment interestingly promotes an increase in the treated material corrosion resistance ${ }^{20,22-24}$, possibly due to the combined effect of the $\mathrm{Cr}$ kept in the steel matrix solid solution and the protective layer formation ${ }^{23,25}$. Regarding the plasma, the pressure increase promotes an increase in electron and atomic nitrogen densities ${ }^{26}$. Differently, only one work was 
found on the pulse voltage effect, which showed slight layer hardness increase for an $\mathrm{ASS}^{28}$.

Considering the carburizing treatment, authors of this work have previously studied the influence of the carburizing gas mixture and flow rate ${ }^{41}$, and the carburizing temperature and time ${ }^{17}$ on the layer formation in the MSS. So, in this work, the influence of the pulse voltage and the (gas) pressure on the MSS carburizing process carried out in a pulsed direct current $(d c)$ abnormal glow discharge is investigated. The main goal of this work is to contribute to the understanding of how these two carburizing glow discharge parameters and the respective plasma constitution can be directly related to the carburized layer formation process in the present treatment.

\section{Bases for the Carburizing Treatment in $D C$ Glow Discharge}

In the LTPC process, time is an independent parameter, differently from the temperature, which is strongly dependent on the glow discharge and/or electrical parameters. Regarding the pulsed $d c$ plasma thermochemical treatments, pulsed wave (voltage and duty cycle) parameters and pressure strongly affect the number density and energy of plasma species $^{42-44}$. Such parameters are the main responsible to control the treatment temperature of substrates or parts acting as cathode in the abnormal glow discharge regime, which depends on the plasma species bombardment ${ }^{45}$. They also present significant technological importance. When separately working, pressure influences the species mean free path, while the applied pulse voltage influences the average electrons energy, plasma density and energy of ions bombarding the cathode surface ${ }^{42,46,47}$. Differently, considering these two parameters working together, for a $d c$ plasma process, the Davis and Vanderslice (1963) rule is supposed to operate. This rule predicts that the product between pressure $(p)$ and cathode sheath thickness $(d)$ tends to be constant for a specific voltage kept unaltered ${ }^{48}$. It means that for a constant voltage, the effect of pressure on the ions energy distribution is small, since rising or reducing the pressure implies in reducing or rising the cathode sheath thickness, respectively, so that a relatively constant number of collisions in the cathode sheath, which directly infer changes on the species energy, can be expected. Differently, for a constant pressure, the increase of the voltage promotes an increase on the cathode fall and a respective reduction on the cathode sheath thickness, thus the ions average energy also increases ${ }^{48}$. Such aspects associated with the inelastic collision processes ${ }^{49}$ leading reactive species to be formed summarize how the reactive species density directly influence the physical-chemical interactions in the plasma-surface interface, thus on the thermochemical treatment result. In this case, it is worth mentioning different phenomena occurring such as the edge effect ${ }^{19,20}$, sputtering ${ }^{42-44,50,51}$, active species generation $^{52,53}$, and the cathode (samples) heating, which in the practice is a function of the pulse switched-on time or duty cycle $\left(t_{o n}\right)^{51}$.

\section{Experimental Procedure}

\subsection{Materials}

Cylindrical samples of AISI 420 steel (for a composition of $0.17 \% \mathrm{C}, 0.70 \% \mathrm{Mn}, 0.50 \% \mathrm{Si}, 12.22 \% \mathrm{Cr}, 0.16 \% \mathrm{Ni}$,
$0.23 \% \mathrm{P}, 0.03 \% \mathrm{~S}, 0.03 \% \mathrm{~N}, 0.01 \% \mathrm{Cu}, 0.02 \% \mathrm{Co}$, and balance in $\mathrm{Fe}$, in wt. \%) were cut to $10 \mathrm{~mm}$ in height from a $9.5 \mathrm{~mm}$ diameter commercial rod supplied in annealed state. In order to obtain a fully martensitic structure ${ }^{54-56}$, samples were austenitized at $1050{ }^{\circ} \mathrm{C}$ for $0.5 \mathrm{~h}$ and oil quenched, reaching in this as-quenched state an average hardness of $510 \pm 10 \mathrm{HV}_{0.3}$. Before LTPC treatment, samples were ground using $\mathrm{SiC}$ sandpaper up to 1200 grade and mirror polished using $1 \mu \mathrm{m} \mathrm{Al}_{2} \mathrm{O}_{3}$ suspension, which resulted for average $R a$ and $R z$ roughness values of $0.070( \pm 0.008)$ and $0.320( \pm 0.027) \mu \mathrm{m}$, respectively. Afterwards, samples were cleaned in ultrasonic bath using isopropyl alcohol, dried under heated airflow and introduced into the glow discharge chamber.

\subsection{The LTPC processing}

Scheme and complete description of the plasma treatment apparatus utilized in this study can be found in ref ${ }^{57}$. After evacuating the system to a pressure of $4 \mathrm{~Pa}$ (30 mTorr), samples were subjected to (plasma) sputter-cleaning at $300{ }^{\circ} \mathrm{C}$, for $0.5 \mathrm{~h}$, in an $80 \% \mathrm{H}_{2}+20 \%$ Ar gas mixture, for flow rate of $1.67 \times 10^{-6} \mathrm{Nm}^{3} \cdot \mathrm{s}^{-1}(100 \mathrm{sccm})$, under $400 \mathrm{~Pa}$ (3 Torr) pressure. As-quenched samples were carburized at $450{ }^{\circ} \mathrm{C}$, for $8 \mathrm{~h}$, in $99.5 \%\left(80 \% \mathrm{H}_{2}+20 \% \mathrm{Ar}\right)+0.5 \% \mathrm{CH}_{4}$ gas mixture, keeping the same pressure and flow rate used in the previous (plasma) sputter-cleaning step. In the present study, as-quenched samples were simultaneously tempered during the plasma carburizing treatment, as expected from the thermal effect; being of interest details about the steel tempering can be found in $\mathrm{ref}^{58}$. Once concluded the carburizing step samples were cooled down to room temperature under $\mathrm{H}_{2}+$ Ar gas mixture flow.

Two treatment series using a $4.16 \mathrm{kHz}$ square-wave pulsed $d c$ power supply and a pulse period of $240 \mu$ s were carried out:

i. one, varying the pulse voltage parameter for 500 , 600 , and $700 \mathrm{~V}$ at a fixed pressure of $400 \mathrm{~Pa}$. For these treatments the $t_{\text {on }}$ (the pulse switched-on time or duty cycle) was $136( \pm 4), 70( \pm 1)$ and $47( \pm 1)$ $\mu \mathrm{s}$, and the electrical current was $166( \pm 3), 144$ $( \pm 3)$ and $133( \pm 3) \mathrm{mA}$, respectively; and

ii. the other, varying the pressure for 200, 400, and $800 \mathrm{~Pa}(1.5,3$ and 6 Torr, respectively) at a fixed pulse voltage of $700 \mathrm{~V}$ (actual $688 \pm 12 \mathrm{~V}$ ). For these treatments the $t_{\text {on }}$ was $128( \pm 2), 50( \pm 1)$ and $50( \pm 1) \mu \mathrm{s}$, and the electrical current was $126( \pm 7)$, $137( \pm 2)$ and $169( \pm 2) \mathrm{mA}$, respectively.

The observed $t_{\text {on }}$ values needed to attain the treatment temperature and the current dependence on this independent parameter, namely the $t_{o n}$, is explained by the LTPC working in the abnormal glow discharge regime, as observed in $\operatorname{ref}^{50,51,59,60}$.

\subsection{The glow discharge characterization}

In order to qualitatively evaluate the emitting plasma species as a function of the applied pulse voltage and pressure, and aiming at relating the different obtained plasmas with the respective treated surface layers characteristics, experiments 
were separately conducted for optical emission spectroscopy (OES) measurements. For the purpose to avoid possible variations in experimental setup, which would forbid line intensity comparisons, OES measurement experiments were not carried out during the actual treatments. For this case, measurements were performed using an HR4000 Ocean Optics Spectrometer equipped with a 3648-element linear CCD array and a 300 lines $/ \mathrm{mm}$ grating, set to operate in the range of 200-1100 nm, with a wavelength resolution of $1.3 \mathrm{~nm}$ FWHM (full width at half maximum). In the related experiments, for the first series, nominal applied pulse voltage was changed starting from $500 \mathrm{~V}$, and adding $100 \mathrm{~V}$ each $60 \mathrm{~min}$. For the second series, the pressure was initiated at $200 \mathrm{~Pa}$, and it was changed to 400 , and after to $800 \mathrm{~Pa}$, keeping a $60 \mathrm{~min}$ permanence time for each adjusted pressure. In both cases, optical spectra were collected from the beginning of the parameter setting (pressure or pulse voltage) until the end of the $60 \mathrm{~min}$, even if the steady state in OES was attained in the first $5 \mathrm{~min}$. Each spectrum was collected as an average of 30 spectra of 1 second of exposure time, in steady state operation. During such experiments, the $t_{\text {on }}$ was adjusted as a function of the applied pulse voltage and pressure, in order to maintain the temperature at $450^{\circ} \mathrm{C}$. It is to be noted that the experiment was designed this way aiming to ensure the same measurement solid angle (optical fiber was fixed in the same position all long the measurement series), so the emission spectra for each applied pulse voltage and pressure condition of interest was acquired without any changes in the OES experimental setup. As the position between sample and optical fiber was kept unaltered, the relative intensity of the obtained emission lines, of the normalized spectra, can be confronted.

\subsection{The treated samples characterization}

Carburized samples were cross-sectioned and prepared for microstructural characterization according to conventional metallographic preparation procedures. Villela's reagent (95 $\mathrm{ml}$ of ethyl alcohol, $5 \mathrm{ml}$ of hydrochloric acid, and $1 \mathrm{~g}$ of picric acid) was used to reveal the microstructure. Microstructural analysis was performed employing a Confocal Laser Scanning Microscope (Olympus LEXT OLS 3000); this same equipment was used to determine the average $R a$ and $R z$ roughness of treated surfaces, but in this case using a 200x magnification, applying low-pass filtering and slices number suggested by the software dedicated to the microscope control. The determination of carburized layer phases by Xray diffraction (XRD) was carried out as previously indicated in ref $^{16}$. Vickers (HV) and Knoop (HK) microhardness measurements were also performed applying a load of $10 \mathrm{gf}$ during $15 \mathrm{~s}$. For the former, indentations were made in the central part of carburized (top) and non-carburized (bottom) flat surfaces, at a distance of $100 \mu \mathrm{m}$ from each other. For the latter, the respective hardness profiles were obtained, being the measurement distance along the depth fixed in $10 \mu \mathrm{m}$. All indicated hardness values correspond to the average and standard deviation of five measurements performed for each indicated point, being that in graphics, each point presents error bars representing the dispersion of the measured values around the mean value. Finally, the carburized layer depth was determined by means of hardness profiles, using a similar procedure as proposed in NHT standard (DIN 50190-3:1979-03 used in nitriding), which consists in finding the depth where the hardness is $50 \mathrm{HV}$ higher than that of the substrate bulk, but for the present case it was used $50 \mathrm{HK}$ as reference.

\section{Results and Discussion}

\subsection{Microstructural aspects and treated surface characteristics}

All carburized samples showed a predominantly-whiteaspect layer at the treated surfaces. Two typical microstructures of the applied pulse voltage and pressure treatment series are presented in Figure 1a, b, one obtained at $500 \mathrm{~V} / 400 \mathrm{~Pa}$ and the other at $800 \mathrm{~Pa} / 700 \mathrm{~V}$, just the lower voltage and the higher pressure studied here, respectively. This result clearly indicates that the carburized layer it is more chemically resistant to the etching with Villela's reagent than the sample substrate bulk. The white-aspect layer occurrence suggests carbon diffusing and enriching in interstitial solid solution
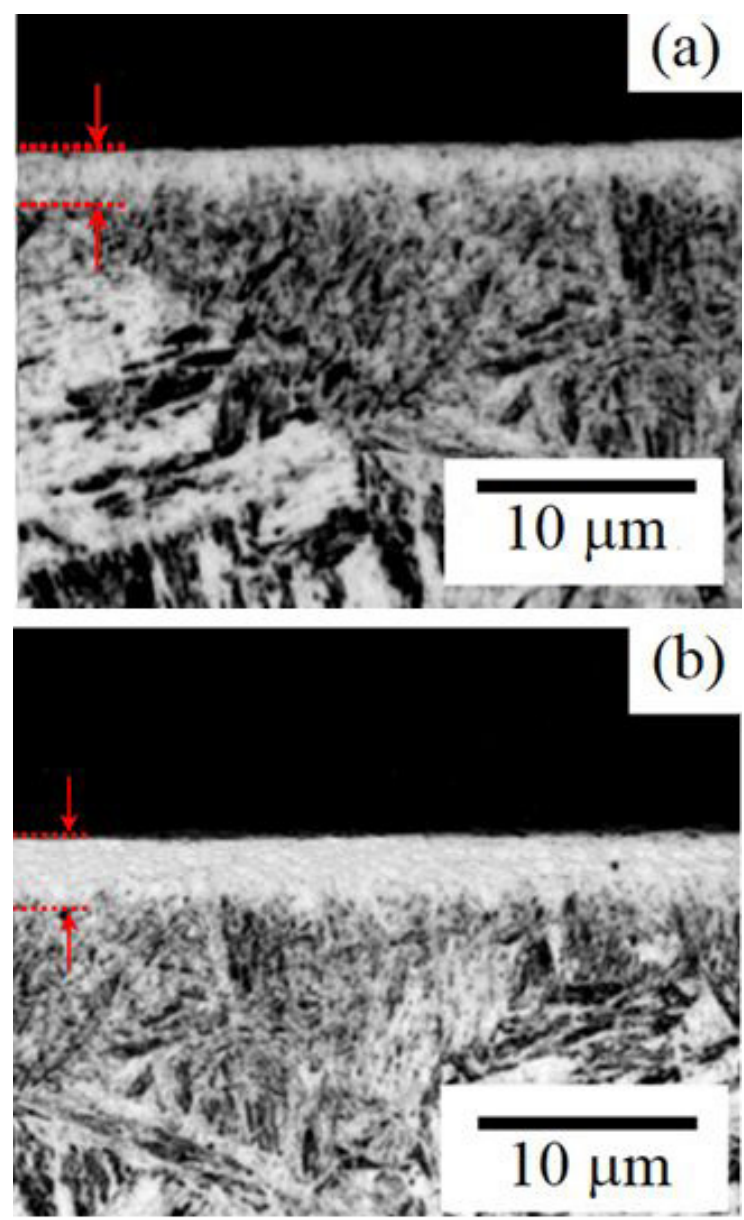

Figure 1. Typical cross-section microstructures of the applied pulse voltage and pressure treatment series obtained at: a) $500 \mathrm{~V} / 400 \mathrm{~Pa}$; and b) $800 \mathrm{~Pa} / 700 \mathrm{~V}$, respectively. Treatments carried out at $450{ }^{\circ} \mathrm{C}$, for $8 \mathrm{~h}$, using $99.5 \%\left(80 \% \mathrm{H}_{2}+20 \% \mathrm{Ar}\right)+0.5 \% \mathrm{CH}_{4}$ gas mixture at $1.67 \times 10^{-6} \mathrm{Nm}^{3} \mathrm{~s}^{-1}$ flow rate. 
the surface martensitic structure, promoting the formation of the termed 'outer layer', according to the terminology previously used in ref ${ }^{41}$. The occurrence of diffusion layer, mainly formed by the carbon interstitial solid solution into the substrate bulk cannot be visualized in the micrographs, being only identified through the hardness profiles, as presented ahead.

Figure 2a, b left y-axis shows Vickers hardness values measured on the carburized (top) and non-carburized (bottom) flat surfaces, obtained for the applied pulse voltage and pressure treatment series, respectively. The top surface hardness grows slightly with increasing of the applied pulse voltage, exhibiting values of $912 \pm 24,975 \pm 26$ and $1022 \pm 23 \mathrm{HV}_{0.01}$ for samples carburized at 500, 600 and $700 \mathrm{~V}$, respectively. The hardness values measured on the bottom surface, in this order, were $392 \pm 28,387 \pm 33$, and $402 \pm 28 \mathrm{HV}_{0.01}$. Comparatively, results indicate a hardness increase on the order of $250 \%$ for the carburized surfaces, being slightly lower at $500 \mathrm{~V}$, and a hardness decrease on the order of $20 \%$ for all non-carburized surfaces due to the steel tempering effect, a result valid for both the studied series. Differently, the carburized surface hardness shows to be sensitive to the pressure parameter. In this case, by varying the pressure from 200 to $400 \mathrm{~Pa}$, a considerable hardness increase from $813 \pm 36$ to $1022 \pm 23 \mathrm{HV}_{0.01}$ was verified, the same being not valid by changing it from 400 to $800 \mathrm{~Pa}$, which hardness slightly decreases from $1022 \pm 23$ and $966 \pm 25 \mathrm{HV}_{0.01}$, respectively.

Figure $2 \mathrm{a}, \mathrm{b}$ right $\mathrm{y}$-axis shows the obtained outer layer thickness and average treated surface $R a$ and $R z$ roughness variation. The layer thickness data demonstrate similar behavior to those obtained for the measured hardness, confirming that thicker layers tend to be harder than the thinner ones. In this case, a slight increase ranging from 1.9 to $2.2 \mu \mathrm{m}$ was observed by increasing the pulse voltage from 500 to $700 \mathrm{~V}$. The higher pulse voltage the higher is the average plasma species ${ }^{\dagger}$ bombardment energy, favoring the MSS oxide layer destabilization and sputtering of the surface atoms. Note that the mean electrical current needed to achieve the treatment temperature decreased from $166 \mathrm{~mA}$ (for $t_{\text {on }}=136 \mu \mathrm{s}$ ) to $133 \mathrm{~mA}$ (for $t=47 \mu \mathrm{s}$ ) when the pulse voltage was increased from 500 to $700 \mathrm{~V}$, respectively. As previously indicated, the measured electrical parameters variation is due to the fact that the treatment has occurred in the abnormal glow discharge regime, in which the current approximately vary linearly with the applied voltage, also being a function of the duty cycle $\left(t_{o n}\right)$ for the case of a pulsed dc glow discharge. In other words, this explains why for the $700 \mathrm{~V}$ voltage condition was needed a $t_{\text {on }}$ value about three times smaller than that observed at $500 \mathrm{~V}$ voltage. Finally, since the cathode temperature is dependent on the ion current density and the thermal losses to the surrounding walls (from the grounded anode, which is constituted by thermal shields and discharge chamber walls), this explains the observed roughly similar current values independently of the utilized pulse voltage.

In addition, the pulse voltage increment also intensifies the electron impact ionization collisions, thus the molecules species dissociation rate. Such effects tend to increase the

$\dagger$ ions and fast neutrals produced from symmetrical and asymmetrical charge change collisions in the cathode sheath ${ }^{38-49}$. carbon precursor active species concentration and atomic carbon available on the treating surface, which is able to diffuse into samples. All these combined effects allied to the fact that the surface carbon enrichment in this LTPC process is diffusion-controlled / -limited ${ }^{16}$ help to explain the slight increase on both the carburized layers thickness $(\sim 0.3 \mu \mathrm{m})$ and hardness $\left(<110 \mathrm{HV}_{0.01}\right)$. Similarly, the above-presented relation between the layer thickness and its hardness was also observed for the pressure treatment series, which showed a $1.7 \mu \mathrm{m}$ thinner layer at $200 \mathrm{~Pa}$, and approximately equal thicker layers for samples treated at 400 and $800 \mathrm{~Pa}$, both close to $2.2 \mu \mathrm{m}$ thickness. This result also indirectly indicates a possible increase on the active species and plasma densities. Additionally, pressure also influences the plasma species collision frequency and the mean free path of gas particles ${ }^{42,43,47,49}$. This means that one can expect a greater frequency of collisional processes, influencing the formation of $\mathrm{CH}_{\mathrm{i}}(\mathrm{i}=0,1,2,3)$ reactive species, thus enhancing the carbon-based reactive species production from $\mathrm{CH}_{4}$ molecules ${ }^{61}$. On the other hand, the shortening of the mean free path at higher pressures will cool down electrons, and, for too high pressure, the dissociative collisions effectiveness can decrease. Based on this reasoning, the relatively small outer layer thickness and hardness for samples treated at $200 \mathrm{~Pa}$ can be justified by the lower carbon atoms density supplied by the plasma to the treating surface. Furthermore, the similarity of the findings for the conditions of 400 and $800 \mathrm{~Pa}$ is possibly justified by the fact that for the higher treatment pressures, the carbon supplying supposedly was not altered significantly. Such results mean a condition for which an active species yielding steady state was reached, probably associated to the eventual thermalization or, differently, the carbon supplying was greater than the capacity of the material to absorb it, strongly indicating that the treatment became a diffusion-limited process, as previously already indicated here. Finally, another and very probable assumption to explain the difference obtained at $200 \mathrm{~Pa}$, regarding the similar results at 400 and $800 \mathrm{~Pa}$, is the well-known role of the atomic hydrogen in promoting decarburization, as discussed from OES results, presented ahead.

Figure $2 \mathrm{a}, \mathrm{b}$ right $\mathrm{y}$-axis also shows the $R z$ and $R a$ roughness of the treated surfaces. Results indicate a slight roughness increase tendency as the pulse voltage is increased. Increasing roughness values of $0.75,0.98$, and $1.0 \mu \mathrm{m}$ for $R z$, and $0.12,0.15$ and $0.18 \mu \mathrm{m}$ for $R a$ were observed for samples carburized at 500, 600 and $700 \mathrm{~V}$, showing significant changes when compared to the starting $0.320 \mu \mathrm{m}$ $R z$ and $0.070 \mu \mathrm{m} R a$ values, respectively. This behavior can be explained by the fact that the energy for which the ions and fast neutrals collide with the substrate surface is directly related to the power transferred to the plasma by the applied voltage ${ }^{42,46,47,49}$, leading the sputtering effect to be also increased. Results also demonstrated that the $R z$ and $R a$ roughness significantly decreases as the pressure is increased from 200 to 400 and $800 \mathrm{~Pa}$, being obtained values of 1.2 , 1.0 and $0.5 \mu \mathrm{m}$ for $R z$ and $0.25,0.23$ and $0.18 \mu \mathrm{m}$ for $R a$, respectively. It is known that the sputtering may promote changes on the samples surface morphology, being strongly dependent on the pressure ${ }^{42}$. The smaller the pressure the higher is its effect at the treated surface, remembering that the 
backscattering phenomenon is enhanced for higher pressures ${ }^{49}$. This means that a larger sputtered atoms density diffuses back to the parent surface, decreasing the sputtering effect on the observed roughness. To the case of the lower pressure $(200 \mathrm{~Pa})$, the larger mean free path may lead sputtered atoms after thermalization to diffuse away from the parent surface, due to the lower backscattering effect, thus resulting in the increment of the surface roughness, as observed in ref ${ }^{42,49}$. In brief, the resulting higher sputtered atoms redeposition rate for the highest studied pressure $(800 \mathrm{~Pa})$ associated to the presumable redeposition of these atoms on valleys of the parent surface would be explain the observed $R z$ and $R a$ roughness reduction. Finally, the electrical parameters variation from $126 \mathrm{~mA}$ (for $t_{\text {on }}=128 \mu \mathrm{s}$ ) at $200 \mathrm{~Pa}$ to $169 \mathrm{~mA}$ (for $t_{o n}=50 \mu \mathrm{s}$ ) at $800 \mathrm{~Pa}$, needed to keep unaltered the treatment temperature, would agree with the higher density of lower-energy ions bombarding the cathode surface at the higher pressure. This increased lower-energy ion density, expected at the higher pressure treatment $(800 \mathrm{~Pa})$ and directly resulting in a higher current seems to compensate in terms of the cathode heating effect the relatively reduced higher-energy ion density, leading to a smaller current at
$400 \mathrm{~Pa}$ treatment pressure, so explaining the same $t_{\text {on }}$ value of $50 \mu$ s observed for both the 400 and $800 \mathrm{~Pa}$ treatments, as confirmed by the measured electrical current for each case, which was $137( \pm 2)$ and $169( \pm 2) \mathrm{mA}$, respectively.

Figure $3 \mathrm{a}$, b shows the Knoop hardness profiles measured on the carburized samples, obtained for the applied pulse voltage and pressure treatment series, respectively. The $2.5 \mu \mathrm{m}$ distance from the surface, observed for the first measurement performed in the samples cross-section, is greater than the obtained outer layers thickness. To clarify, the outer layer region (constituted of $\alpha^{\prime}{ }_{\mathrm{C}}+\mathrm{Fe}_{3} \mathrm{C}$ phase) is also indicated in the Figure $3 \mathrm{a}, \mathrm{b}$ detail. In addition, all hardness profiles confirm the existence of typical diffusion layers showing a smooth hardness decrease from the treated surface to the tempered substrate bulk. Carburized layer depth on the $\sim 40-45 \mu \mathrm{m}$ range was obtained for all studied conditions, with the exception of that obtained at $200 \mathrm{~Pa}$, which presented $\sim 25 \mu \mathrm{m}$ depth and, comparatively, the smaller hardness value at the $2.5 \mu \mathrm{m}$ depth. Hardness values of $845 \pm 16,877 \pm 11$ and $882 \pm 12 \mathrm{HK}_{0.01}$ for samples carburized at 500, 600, and $700 \mathrm{~V}$, and $643 \pm 15,860 \pm 12$ and $812 \pm 10 \mathrm{HK}_{0.01}$ for
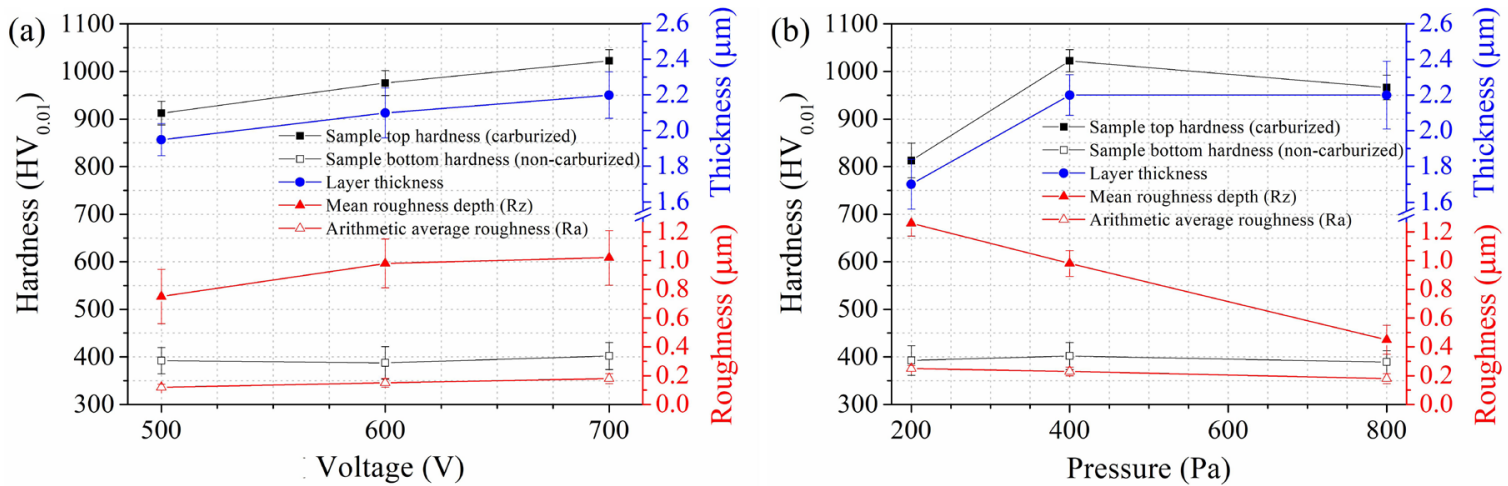

Figure 2. Vickers hardness measured on the carburized (top) and non-carburized (bottom) flat surfaces, layer thickness, and surface $R a$ and $R z$ roughness obtained for: a) applied pulse voltage; and b) pressure treatment series. Treatments carried out at $450{ }^{\circ} \mathrm{C}$, for $8 \mathrm{~h}$, using $99.5 \%\left(80 \% \mathrm{H}_{2}+20 \% \mathrm{Ar}\right)+0.5 \% \mathrm{CH}_{4}$ gas mixture at $1.67 \times 10^{-6} \mathrm{Nm}^{3} \mathrm{~s}^{-1}$ flow rate.
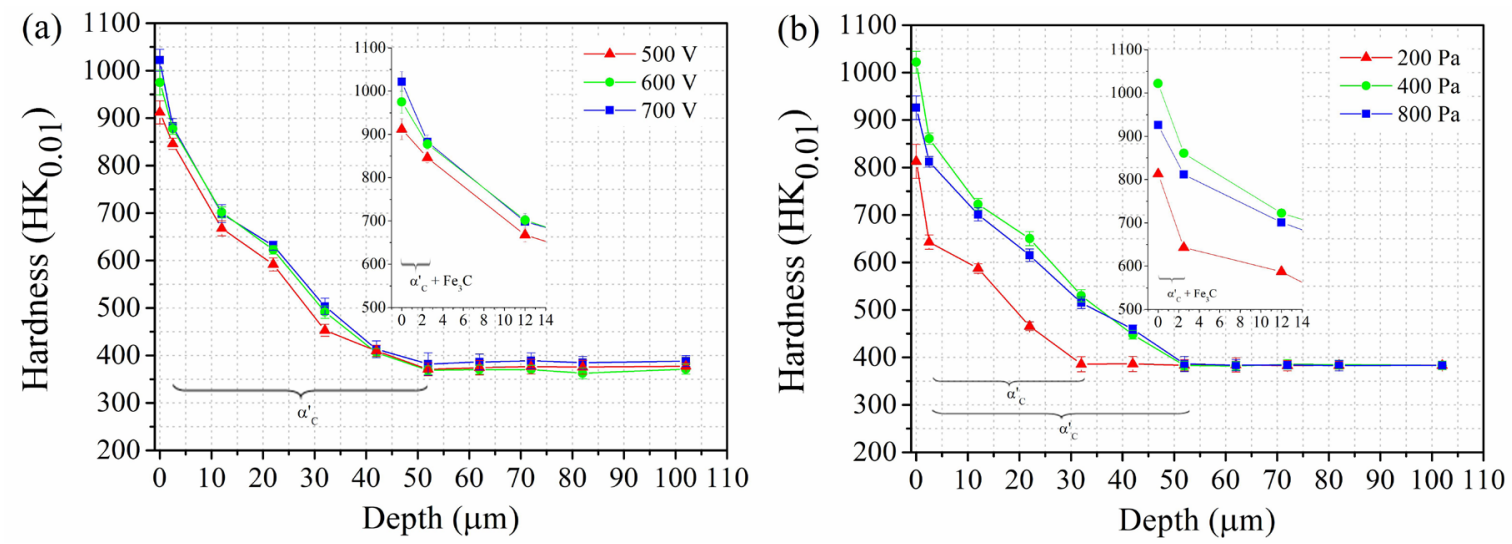

Figure 3. Knoop hardness profiles measured on the carburized samples obtained for: a) applied pulse voltage; and b) pressure treatment series. Treatments carried out at $450{ }^{\circ} \mathrm{C}$, for $8 \mathrm{~h}$, using $99.5 \%\left(80 \% \mathrm{H}_{2}+20 \% \mathrm{Ar}\right)+0.5 \% \mathrm{CH}_{4}$ gas mixture at $1.67 \times 10^{-6} \mathrm{Nm}^{3} \mathrm{~s}^{-1}$ flow rate. 
samples treated at 200, 400 and $800 \mathrm{~Pa}$, were measured to the $2.5 \mu \mathrm{m}$ depth, respectively.

Figure $4 a$, b shows X-ray diffraction patterns of untreated and carburized surfaces, for the applied pulse voltage and pressure treatment series, respectively. All results confirm the obtainment of the carbon-expanded martensite $\left(\alpha^{\prime}\right)$ phase, since the indicated peaks cannot be matched with any other possible phases, including iron and chromium carbides. In addition, the martensite ( $\left.\alpha^{\prime}\right)$ peak initially presented in the untreated sample were broadened and shifted to lower diffraction angles in the carburized samples, indicating lattice parameter expansion by the carbon and residual stress formation, as previously obtained in ref ${ }^{12-14,28,62}$. for LTPC, and in $\mathrm{ref}^{63}$. and $\mathrm{d}^{64}$, for low-temperature solid carburizing and low-pressure carburizing (LPC) techniques, respectively. The $\alpha$ ' phase peak for samples treated at 600 and $700 \mathrm{~V}$ were displaced to smaller angles when compared to that at $500 \mathrm{~V}$. This suggests greater carbon supersaturation for those conditions, being in agreement with the related Figure 2 and 3 results. Moreover, all XRD patterns obtained for samples of both the studied treatment series also show peaks at $39.8^{\circ}$ and $45.9^{\circ}$ that correspond to the cementite $\left(\mathrm{Fe}_{3} \mathrm{C}\right)$ phase (according to the JCPDS card n. 34-0001). Cementite or $\mathrm{Fe}_{3} \mathrm{C}$ phase (in fact, $\mathrm{M}_{3} \mathrm{C}$-type carbide, for which $\mathrm{Cr}$ would partially substitute $\mathrm{Fe}$ atoms) peaks show greater intensities for samples treated at 600 and $700 \mathrm{~V}$, also suggesting the formation of higher iron-based carbide phase volumetric fractions. Regarding the pressure treatment series, changes on the original martensite ( $\left.\alpha^{\prime}\right)$ peak for the sample treated at $200 \mathrm{~Pa}$ are less pronounced than those observed for samples treated at 400 and $800 \mathrm{~Pa}$. This result is related to the possible lower carbon supply that is in agreement with the lower reactive species density for this sample, as previously discussed, disregarding the XRD probing depth, since for this condition (200 Pa) the outer layer is thinner, so that the XRD pattern would have a higher contribution coming from the diffusion layer and lower information coming from the outer layer, when compared to the other studied pressures. Despite the formation of $\mathrm{Fe}_{3} \mathrm{C}$ phase in stainless steels is not common, since chromium carbides are much more stable, its obtainment in the studied samples is due to the LTPC treatment paraequilibrium conditions. As discussed in details in ref $^{65}$, for treatments at relatively low temperatures $\left(\leq 450{ }^{\circ} \mathrm{C}\right)$ the $\mathrm{Fe}$ and $\mathrm{Cr}$ (substitutional elements) diffusivity in the stainless steel matrix is negligible whereas that of the $\mathrm{C}$ (interstitial element) is significant. Since Fe atoms are much more available in a stainless steel alloy than $\mathrm{Cr}$ ones, as expected for a ferrous alloy, the probability for iron carbide phase formation is much higher at paraequilibrium. In other words, chromium carbide phases preferentially tend to be formed at temperatures higher than $450{ }^{\circ} \mathrm{C}$ and/or treatment times longer than $12 \mathrm{~h}$, when the $\mathrm{Cr}$ diffusivity becomes significant, as shown in ref $^{16}$.

To conclude this point, different aspects of the treated surface morphology are shown in Figure 5a, b. Despite it is very well known on the plasma nitriding field ${ }^{66,67}$, no work on edge effect from the plasma carburizing treatment was found in literature. Figure 5a shows the edge effect aspect and hardness variation along the treated surface for samples of the pressure treatment series. This effect presents significant technological interest for $d c$ plasma treatments, usually leading to heterogeneous properties and characteristics varying from the sample or part boundary towards its center at the treated surface, such as those verified here.

So, hardness measurements spaced for $250 \mu \mathrm{m}$ one each other and radially made from the surface into the sample center showed hardness decrease on the order of $50 \mathrm{HV}$ for the studied samples (see Figure 5a), as also shown in ref ${ }^{27,28}$. This result is associated to the higher thermal effect located together the sample boundary associated to a more intense sputtering, suggesting differentiated and located pulverization of carbon atoms condensed at the treating surface. Besides the reduced carbon enrichment in such boundary regions, the higher plasma density due to the sum of two glow regions, one formed on the sample flat surface and the other formed around the sample cylindrical surface, tends to intensify a located tempering effect, thus also contributing to the reduction of its hardness. Figure 5a also shows the
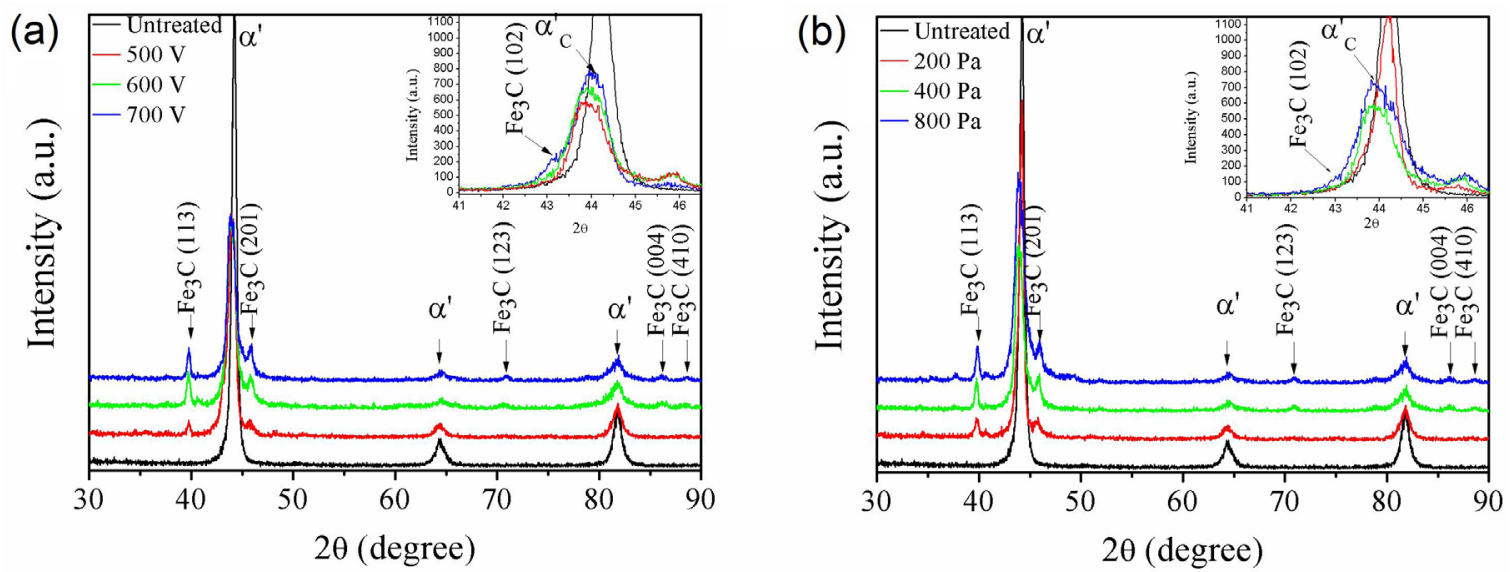

Figure 4. X-ray diffraction patterns of untreated and carburized surfaces obtained for: a) applied pulse voltage; and b) pressure treatment series. Treatments carried out at $450{ }^{\circ} \mathrm{C}$, for $8 \mathrm{~h}$, using $99.5 \%\left(80 \% \mathrm{H}_{2}+20 \% \mathrm{Ar}\right)+0.5 \% \mathrm{CH}_{4}$ gas mixture at $1.67 \times 10^{-6} \mathrm{Nm}^{3} \mathrm{~s}^{-1}$ flow rate. 
flat surface of treated specimens clearly indicating circular marks varying on the order of $1.0,0.5$ and $0.25 \mathrm{~mm}$ were obtained at 200, 400 and $800 \mathrm{~Pa}$, respectively, confirming that more heterogeneous-aspect surfaces are obtained for higher pressures, which tend to reduce this studied effect. So, the edge effect reduction is corroborated by more restricted glow regions that can be achieved using higher treatment applied pulse voltages and/or pressures, causing electric field distortions ${ }^{68}$ only very close to the vicinity of sample boundaries, reducing the cathode sheath thickness,

(a)
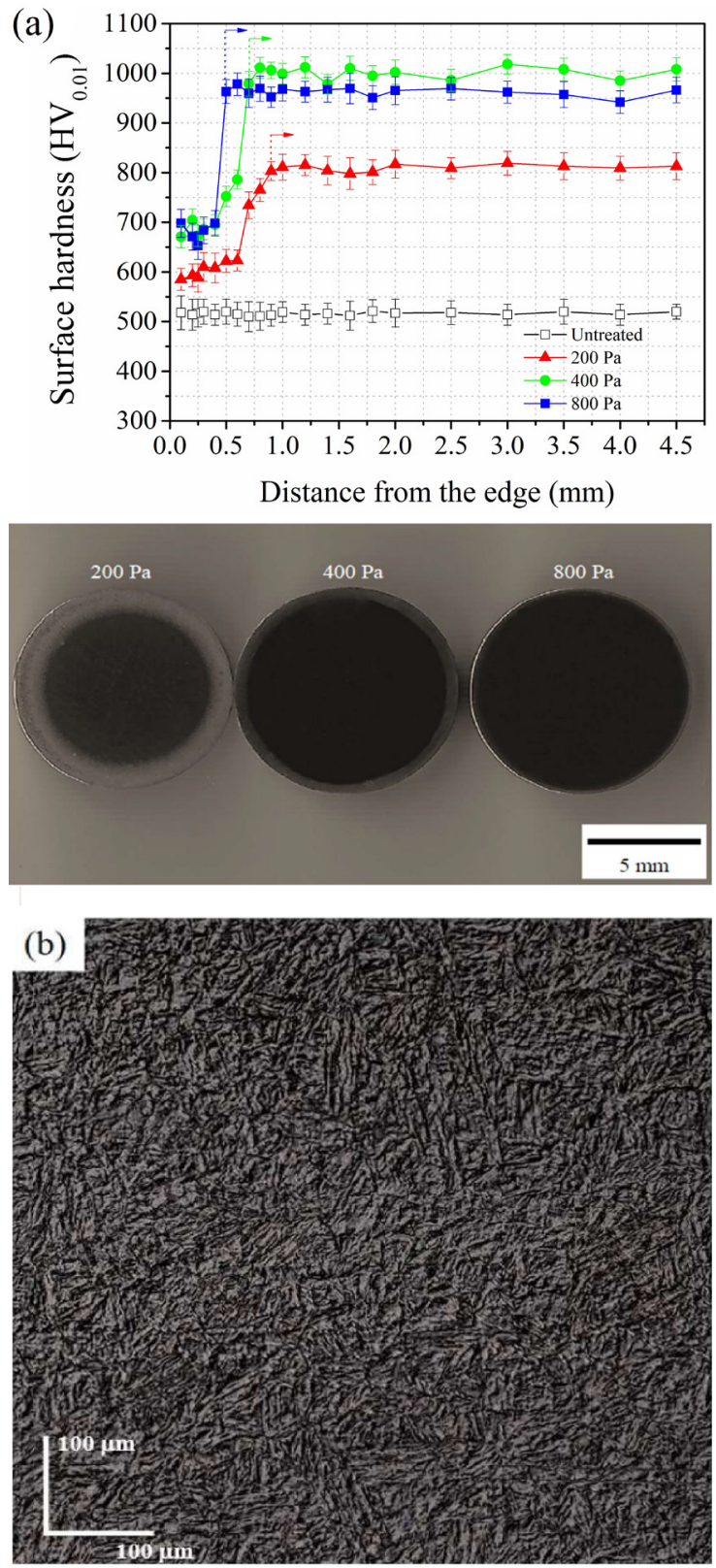

Figure 5. (a) Edge effect aspect and hardness variation along samples of the pressure treatment series; and (b) Typical surface topography images of the sample treated at $800 \mathrm{~Pa} / 700 \mathrm{~V}$. Treatments carried out at $450{ }^{\circ} \mathrm{C}$, for $8 \mathrm{~h}$, using $99.5 \%\left(80 \% \mathrm{H}_{2}+20 \% \mathrm{Ar}\right)+0.5 \%$ $\mathrm{CH}_{4}$ gas mixture at $1.67 \times 10^{-6} \mathrm{Nm}^{3} \mathrm{~s}^{-1}$ flow rate. and leading the plasma to more homogeneously cover each respective surface.

Finally, Figure 5b shows a typical surface morphology image for LTPC treated samples, in this case for the sample carburized at $800 \mathrm{~Pa} / 700 \mathrm{~V}$. This morphology, revealed by sputtering, shows typical coarsened (plate-like) martensite ${ }^{65}$, agreeing very well with the significant increment observed for $R z$ and $R a$ roughness measurements of the treated samples.

\subsection{Glow discharge characteristics used in the LTPC}

Glow discharge spectra of treatments carried out at 500,600 and $700 \mathrm{~V}$ are shown in Figure 6a. It is important

(a)

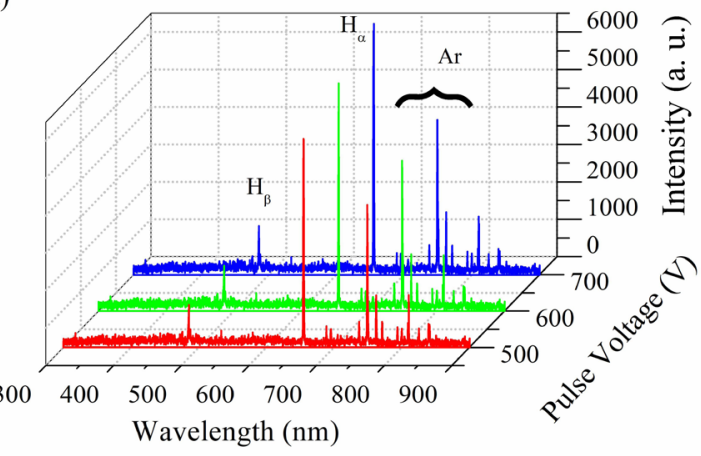

(b)
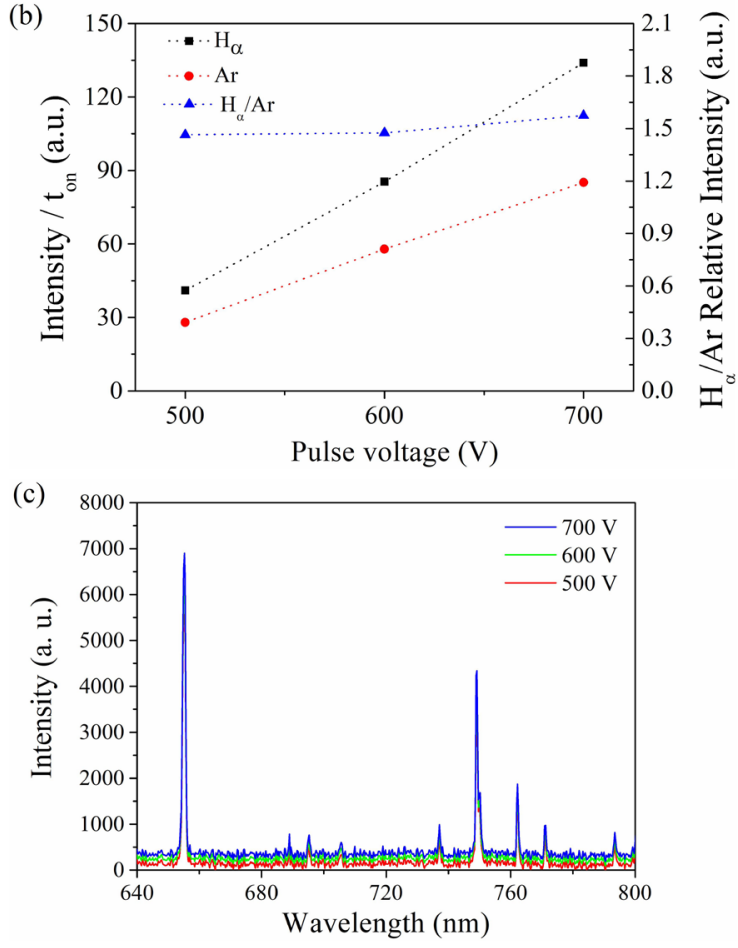

Figure 6. (a) $t_{o n}$-normalized intensity OES spectra of the glow discharge; (b) instantaneous $\mathrm{H}_{\alpha}$ and Ar e.s. emission intensity (represented by the Intensity / $t_{o n}$ axis spectrum evolution) and $\mathrm{H} / \mathrm{Ar}$ e.s. intensity ratio; and (c) global intensity OES spectra (not divided by $t_{o n}$ ), for treatments carried out at 500,600 and 700 V. Treatments carried out at $450{ }^{\circ} \mathrm{C}$, for $8 \mathrm{~h}$, using $99.5 \%(80 \%$ $\mathrm{H}_{2}+20 \% \mathrm{Ar}$ ) $+0.5 \% \mathrm{CH}_{4}$ gas mixture at $1.67 \times 10^{-6} \mathrm{Nm}^{3} \mathrm{~s}^{-1}$ flow rate, and pressure of $400 \mathrm{~Pa}$. 
to observe that in order to maintain the same treatment temperature at a fixed pressure of $400 \mathrm{~Pa}$, using different bias voltage, it was mandatory to adjust the $t_{\text {on }}$ (duty cycle) of the pulsed $d c$ power supply. For this reason, this parameter needed to be took into account when the intensity of the emission lines was analyzed (represented by the Intensity / $t_{\text {on }}$ ordinate axis in Figure 6a, b). This same observation is also valid for the pressure variation study, presented ahead (see Figure 7a, b). For the considered 300-900 nm wavelength range, as shown, the most intense detected emission lines are related to atomic Hydrogen $\left(\mathrm{H}_{\alpha}, \mathrm{H}_{\beta}\right)$ and Argon (Ar) emissive species (e.s.). Hydrogen lines, namely $\mathrm{H}_{\alpha}(656 \mathrm{~nm})$ and $\mathrm{H}_{\beta}(486 \mathrm{~nm})$, and several lines of $\mathrm{Ar}$ in the range of $730-850 \mathrm{~nm}$ are the most intense emissions detected in the studied conditions. Despite the presence of $\mathrm{C}_{\mathrm{x}} \mathrm{H}_{\mathrm{y}}$ species in the plasma, the relative intensity of emission lines from these species was not intense enough to be detected, which is related to the relatively low $\mathrm{CH}_{4}$ number density in the treatment gas mixture. As expected, as the applied voltage rises more intense instantaneous emissions intensity (represented by the Intensity / $t_{\text {on }}$ axis) was verified. This is a result of an increase in the yield of excited (metastable) $\mathrm{H}$ and $\mathrm{Ar}$ species due to the increase of the electron temperature and number density with the increasing pulse voltage. Because of that, a greater instantaneous number density of active species is found, during the switched-on period, when the pulse voltage is augmented. In accordance with Figure $6 \mathrm{~b}$ results, when the emission intensity of atomic Hydrogen $(\mathrm{H})$ and Argon (Ar) emissive species (e.s.) are taken into account, a roughly stable $\mathrm{H}_{\alpha} / \mathrm{Ar}$ e.s. intensity ratio is observed on the 500-700 V range. So, the applied pulse voltage seems to play no important role, despite the very slight observed growing tendency on the relative creation rate of $\mathrm{H}$ and $\mathrm{Ar}$ (e.s.), by increasing the voltage. This result is confirmed in Figure $6 \mathrm{c}$ by the approximately equal spectra in the three studied conditions when considering the global intensity (not divided by $t_{o n}$ ), indicating that the pulse voltage has similar influence on the creation mechanism of $\mathrm{H}$ and $\mathrm{Ar}$ (e.s.). Considering that such species are mainly created by electron impact, probably the same behavior is also valid for $\mathrm{C}_{\mathrm{x}} \mathrm{H}_{\mathrm{y}}$ species. It suggests that in the studied pulse voltage range, the variation of this parameter more significantly modifies the electron number density than its energy distribution.

Glow discharge spectra of treatments carried out at 200, 400 and $800 \mathrm{~Pa}$ are shown in Figure 7a. Atomic Hydrogen (H) and Argon (Ar) emissive species (e.s.) were again the most intense emissions detected. However, differently of the results obtained from the pulse voltage variation, quite distinct spectra by increasing the treatment pressure from 200 to $800 \mathrm{~Pa}$ were obtained. As can be noted in Figure 7a, b, by varying the treatment pressure from 200 to $400 \mathrm{~Pa}$, the spectra intensity is increased, but an intensity drop is observed by increasing the pressure from 400 to $800 \mathrm{~Pa}$. Such drop should be related to the smaller mean free path at higher pressures, as also evidenced in results of the $\operatorname{ref}^{19}$, which would result in less energetic collisions, thus in a fall of the respective intensities. In addition, by analyzing the region from 640 to $840 \mathrm{~nm}$ (see Figure 7a), a more significant drop for $\mathrm{H}_{\alpha}$ than that of the $\mathrm{Ar}$ (e.s.) at $750 \mathrm{~nm}$ occurs when the pressure is increased (Figure 7c). This change in the relative intensity
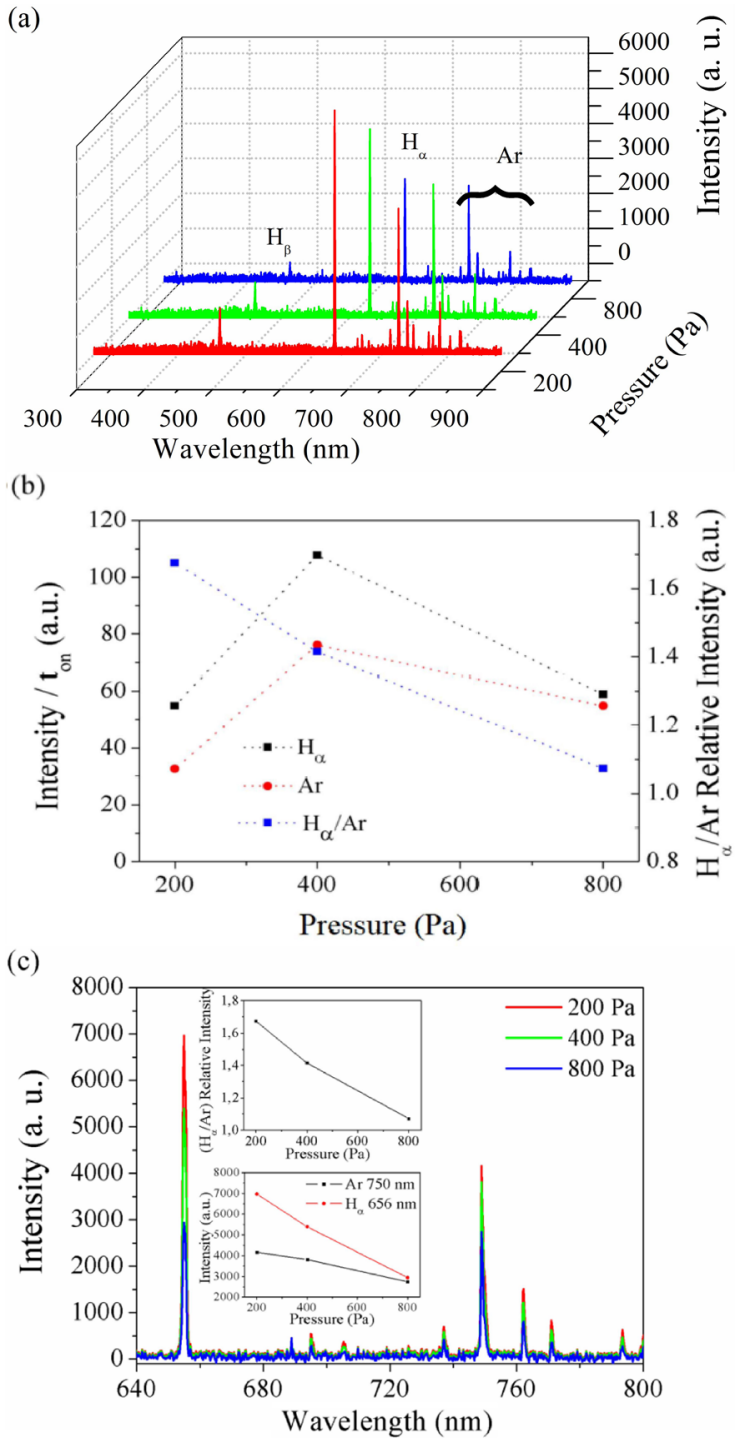

Figure 7. (a) $t_{o n}$-normalized intensity OES spectra of the glow discharge; (b) instantaneous $\mathrm{H}_{\alpha}$ and Ar e.s. emission intensity (represented by the Intensity / $t_{\text {on }}$ axis spectrum evolution) and $\mathrm{H}_{\alpha} /$ Ar e.s. intensity ratio; and (c) global intensity OES spectra (not divided by $t_{o n}$ ), for treatments carried out at 200, 400 and $800 \mathrm{~Pa}$. Treatments carried out at $450{ }^{\circ} \mathrm{C}$, for $8 \mathrm{~h}$, using $99.5 \%\left(80 \% \mathrm{H}_{2}+\right.$ $20 \% \mathrm{Ar})+0.5 \% \mathrm{CH}_{4}$ gas mixture at $1.67 \times 10^{-6} \mathrm{Nm}^{3} \mathrm{~s}^{-1}$ flow rate, and voltage of $700 \mathrm{~V}$.

ratio (Figure $7 b$ ) means that there is a considerable change in the plasma species energy distribution on the studied pressure range. Kobashi ${ }^{69}$ stated that the $\mathrm{H} \alpha / \mathrm{Ar}$ (e.s.) intensity ratio provides an approximated measure for atomic hydrogen (H) number density in plasma. So, this result can bring an additional interpretation for the treated surface hardness and hardness profile variation with the treatment pressure. Atomic hydrogen $(\mathrm{H})$ is known to promote decarburizing, so when carbon active species condense on and react with the surface, there is a competition between its diffusion towards the substrate bulk and the surface decarburizing. Thus, a high $\mathrm{H}$ number density in the plasma atmosphere can lead 
to a relatively lower actual carburizing potential along the treatment. Finally, considering obtained data of XRD, and the hardness and treated layer thickness characterization, it seems clear that the $\mathrm{H}$ number density plays an important role on the low-temperature plasma carburizing. For the studied conditions, higher pressures (400 and $800 \mathrm{~Pa}$ ) were more effective to produce $\alpha_{\mathrm{C}}$, hard layers than the lower pressure $(200 \mathrm{~Pa})$, which agrees very well with its higher $\mathrm{H}$ number density in the plasma atmosphere (see Figure 7c). It is assumed that the higher $\mathrm{H}$ number density at $200 \mathrm{~Pa}$ is related to a relatively lower actual carburizing potential, as suggested from Figure 2, 3, and 4a, b results for the present case, as well as a higher dissociation rate of the molecular $\mathrm{H}_{2}$ species.

\section{Conclusions}

A study strengthened by an optical emission spectroscopy approach for low-temperature plasma carburizing was performed aiming to evaluate the influence of the treatment pressure and applied pulse voltage on the glow-discharge characteristics, and on surface properties of the treated AISI 420 martensitic stainless steel. The main conclusions of this work are:

- The variation of the applied pulse voltage, in the studied range, does not significantly influence the surface characteristics of treated samples. The average values of outer layer hardness and thickness as well as the treated surface roughness grow modestly with the pulse voltage varying from 500 to $700 \mathrm{~V}$;

- The variation of the treatment pressure leads to significant changes in the surface characteristics of the treated samples. Pressures of 400 and $800 \mathrm{~Pa}$ are responsible by the most promising results for the outer layer thickness and hardness. Likewise, surface roughness as well as edge effect decrease with the increment of the pressure; and

- Optical emission spectroscopy (OES) showed to be an important complementary technique to give support for the findings obtained in this work. Optical emissions spectra are in agreement with the metallurgical results that indicate more effective carburizing treatments occurring for pressures of 400 and $800 \mathrm{~Pa}$. Results evidenced for the lower pressure $(200 \mathrm{~Pa})$ suggest the significant decarburizing role played by the atomic hydrogen. Comparatively, the dissociation rate of the molecular $\mathrm{H}_{2}$ species tends to be significantly affected by the pressure parameter.

\section{Acknowledgements}

This work was supported by CAPES (Coordenação de Aperfeiçoamento de Pessoal de Nivel Superior-Brasil-Finance Code 001), CNPq (Conselho Nacional de Desenvolvimento Científico e Tecnológico), CNPq-Universal Grant N. 482380/2012-8, MCTI/CNPq/CT-Aquaviário Grant N. 456347/2013-5 and Fundação Araucária do Estado do Paraná
(PRONEX - Grant N. 46744). Dr. M. Mafra thanks to CNPq by the financial support through Process n. 311716/2018-0. Dr. C.J. Scheuer thanks to FAPERGS (Research Support Foundation of the Rio Grande do Sul State) by the financial support through Grant N. 19/2551-0001749-9. The authors also wish to express thanks to the Laboratory of X-ray Optics and Instrumentation - LORXI, by the use of the X-ray diffraction equipment, and Integrated Laboratories of Materials and Surface Treatments - LaMaTS, by the use of the confocal laser scanning microscope equipment, both laboratories from the Universidade Federal do Paraná (UFPR).

\section{References}

1. Zhou Y, Engelberg DL. Accessing the full spectrum of corrosion behaviour of tempered type 420 stainless steel. Mater. Corros. 2021:1-12. https://doi.org/10.1002/maco.202112442.

2. Morshed-Behbahani K, Najafisayar P, Zakerin N, Pakshir M. A detailed electrochemical analysis of sensitized AISI 410 martensitic stainless steel. Mater Res Express. 2021;8(5):056501. http://dx.doi.org/10.1088/2053-1591/abfa4a.

3. Pinedo CE, Monteiro WA. On the kinetics of plasma nitriding a martensitic stainless steel type AISI 420. Surf Coat Tech. 2004;179(2-3):119-23. http://dx.doi.org/10.1016/S02578972(03)00853-3.

4. Wu K, Liu GQ, Wang L, Xu BF. Research on new rapid and deep plasma nitriding techniques of AISI 420 martensitic stainless steel. Vacuum. 2010;84(6):870-5. http://dx.doi.org/10.1016/j. vacuum.2009.12.001.

5. Kim SK, Yoo JS, Priest JM, Fewell MP. Characteristics of martensitic stainless steel nitrided in a low-pressure RF plasma. Surf Coat Tech. 2003;163-164:380-5. http://dx.doi.org/10.1016/ S0257-8972(02)00631-X.

6. Xi Y, Liu D, Han D. Improvement of corrosion and wear resistances of AISI 420 martensitic stainless steel using plasma nitriding at low temperature. Surf Coat Tech. 2008;202(12):2577-83. http://dx.doi.org/10.1016/j.surfcoat.2007.09.036.

7. Ak D, Ad P, Bhadania AG. Stainless steel for dairy and food industry: a review. J Mar Sci Eng. 2015;4:1-4. http://dx.doi. org/10.4172/2169-0022.1000191

8. Barbosa C, Abud I. Recent developments on martensitic stainless steels for oil and gas production. Recent Pat Corros Sci. 2013;3(1):27-38. http://dx.doi.org/10.2174/22106839112 029990004.

9. Cortie MB, McEwan JJ, Enright DP. Materials selection in the mining industry: old issues and new challenges. J S Afr Inst Min Metall. 1996;96:145-57. https://doi.org/10520/ AJA0038223X_2375.

10. Li CX, Bell T. A comparative study of low temperature plasma nitriding, carburising and nitrocarburising of AISI 410 martensitic stainless steel. Mater Sci Technol. 2007;23(3):355-61. http:// dx.doi.org/10.1179/174328407X161204.

11. Lu SY, Yao KF, Chen YB, Wang MH, Chen N, Ge XY. Effect of quenching and partitioning on the microstructure evolution and electrochemical properties of a martensitic stainless steel. Corros Sci. 2016;103:95-104. http://dx.doi.org/10.1016/j. corsci.2015.11.010.

12. Scheuer CJ, Possoli FAA, Borges PC, Cardoso RP, Brunatto SF. AISI 420 martensitic stainless steel corrosion resistance enhancement by low-temperature plasma carburizing. Electrochim Acta. 2019;317:70-82. http://dx.doi.org/10.1016/j. electacta.2019.05.101.

13. Severo FS, Scheuer CJ, Cardoso RP, Brunatto SF. Brunatto, Cavitation erosion resistance enhancement of martensitic stainless steel via low-temperature plasma carburizing. Wear. 2019;428429:162-6. http://dx.doi.org/10.1016/j.wear.2019.03.009. 
14. Angelini V, Boromei I, Martini C, Scheuer CJ, Cardoso RP, Brunatto SF, et al. Dry sliding behavior (block-on-ring tests) of AISI 420 martensitic stainless steel, surface hardened by low temperature plasma-assisted carburizing. Tribol Int. 2016;103:55565. http://dx.doi.org/10.1016/j.triboint.2016.08.012

15. Cardoso RP. Low-temperature thermochemical treatments: metastable phases formation and opportunities for new developments. Materia. 2019;24(1):e-12336. http://dx.doi. org/10.1590/s1517-707620180001.0653.

16. Scheuer CJ, Cardoso RP, Mafra M, Brunatto SF. AISI 420 martensitic stainless steel low-temperature plasma assisted carburizing kinetics. Surf Coat Tech. 2013;214:30-7. http:// dx.doi.org/10.1016/j.surfcoat.2012.10.060.

17. Scheuer CJ, Cardoso RP, Pereira R, Mafra MS, Brunatto SF. Low temperature plasma carburizing of martensitic stainless steel. Mater Sci Eng A. 2012;539:369-72. http://dx.doi.org/10.1016/j. msea.2012.01.085.

18. Yin L, Ma X, Tang G, Fu Z, Yang S, Wang T, et al. Characterization of carburized $14 \mathrm{Cr} 14 \mathrm{Co} 13 \mathrm{Mo} 4$ stainless steel by low pressure carburizing. Surf Coat Tech. 2019;358:654-60. http://dx.doi. org/10.1016/j.surfcoat.2018.11.090.

19. Souza SD, Kapp M, Olzon-Dionysio M, Campos M. Influence of gas nitriding pressure on the surface properties of ASTM F138 stainless steel. Surf Coat Tech. 2010;204(18-19):2976-80. http://dx.doi.org/10.1016/j.surfcoat.2010.03.005.

20. Campos M, Souza S, Davim JP, Souza SD, Olzon-Dionysio $\mathrm{M}$. Influence of the gas pressure of plasma nitriding on the structural: mechanical and tribological surface properties of AISI 316L. Mater Res. 2019;22(4):e20190302. http://dx.doi. org/10.1590/1980-5373-mr-2019-0302.

21. Nishimoto A, Nagatsuka K, Narita R, Nii H, Akamatsu K, Canale L, et al. Effect of gas pressure on active screen plasma nitriding response. J ASTM Int. 2011;8(3):1-7. http://dx.doi. org/10.1520/JAI103286.

22. Sousa RRM, Araújo FO, Gontijo LC, Costa JAP, Nascimento IO, Alves C Jr. Cathodic cage plasma nitriding of austenitic stainless steel (AISI 316): influence of the working pressure on the nitrided layers properties. Mater Res. 2014;17(2):427-33. http://dx.doi.org/10.1590/S1516-14392013005000197.

23. Borgioli F, Fossati A, Galvanetto E, Bacci T, Pradelli G. Glow discharge nitriding of AISI 316L austenitic stainless steel: influence of treatment pressure. Surf Coat Tech. 2006;200(1819):5505-13. http://dx.doi.org/10.1016/j.surfcoat.2005.07.073.

24. Wang S, Cai W, Li J, Wei W, Hu J. A novel rapid D.C. plasma nitriding at low gas pressure for 304 austenitic stainless steel. Mater Lett. 2013;105:47-9. http://dx.doi.org/10.1016/j. matlet.2013.04.031.

25. Mendes AF, Scheuer CJ, Joanidis IL, Cardoso RP, Mafra M, Klein NA, et al. Low-temperature plasma nitriding of sintered PIM 316L austenitic stainless steel. Mater Res. 2014;17(Suppl. 1):100-9. http://dx.doi.org/10.1590/S1516-14392014005000064.

26. Naeem M, Zaka-ul-Islam M, Khattak ZI, Shafiq M, Zakaullah $\mathrm{M}$. Influence of argon fraction on plasma parameters in H2-N2 mixture discharge with cathodic cage. Eur Phys J Appl Phys. 2017;77(1):10801. http://dx.doi.org/10.1051/epjap/2016160280.

27. Abd El-Rahman AM, El-Hossary FM, Negm NZ, Prokert F, Richter E, Möller W. Influence of gas pressure and substrate temperature on PIII nitrocarburizing process of AISI 304 stainless steel. Nuclear Instruments and Methods in Physics Research Section B. 2004;226(4):499-506. http://dx.doi.org/10.1016/j. nimb.2004.07.006.

28. Fewell MP, Priest JM, Baldwin MJ, Collins GA, Short KT. Nitriding at low temperature. Surf Coat Tech. 2000;131(13):284-90. http://dx.doi.org/10.1016/S0257-8972(00)00793-3.

29. Dalibon E, Charadia R, Cabo A, Brühl SP. Short time ion nitriding of AISI 420 martensitic stainless steel to improve wear and corrosion resistance. Mater Res. 2019;22(6):e20190415. http://dx.doi.org/10.1590/1980-5373-mr-2019-0415.
30. Allenstein AN, Cardoso RP, Machado KD, Weber S, Pereira KMP, dos Santos CAL, et al. Strong evidences of tempered martensite-to-nitrogen-expanded austenite transformation in CA-6NM steel. Mater Sci Eng A. 2012;552:569-72. http:// dx.doi.org/10.1016/j.msea.2012.05.075.

31. Allenstein AN, Lepienski CM, Buschinelli AJA, Brunatto SF. Plasma nitriding using high $\mathrm{H} 2$ content gas mixtures for a cavitation erosion resistant steel. Appl Surf Sci. 2013;277:1524. http://dx.doi.org/10.1016/j.apsusc.2013.03.055.

32. Allenstein AN, Lepienski CM, Buschinelli AJA, Brunatto SF. Improvement of the cavitation erosion resistance for lowtemperature plasma nitrided Ca-6NM martensitic stainless steel. Wear. 2014;309(1-2):159-65. http://dx.doi.org/10.1016/j. wear.2013.11.002.

33. Kertscher R, Moraes JM, Henke S, Allenstein AN, Silva RHG, Dutra JC, et al. First results of cavitation erosion behavior of plasma nitrided niobium: surface modification. Mater Res. 2015;18(6):1242-50. http://dx.doi.org/10.1590/1516-1439.027515.

34. Scheuer CJ, Zanetti FI, Cardoso RP, Brunatto SF. Ultra-low-to high-temperature plasma-assisted nitriding: revisiting and going further on the martensitic stainless steel treatment. Mater Res Express. 2018;6(2):026529. http://dx.doi.org/10.1088/20531591/aaeca2.

35. Toscano TD, Cardoso RP, Brunatto SF. A novel concept of hybrid treatment for high-hardenability steels: concomitant hardening and paraequilibrium thermochemical treatment to produce interstitially hardened/stabilized austenite surfaces. Steel Res Int. 2020;91(10):2000189. http://dx.doi.org/10.1002/ srin.202000189.

36. Kertscher R, Brunatto SF. On the kinetics of nitride and diffusion layer growth in niobium plasma nitriding. Surf Coat Tech. 2020;401:126220. http://dx.doi.org/10.1016/j. surfcoat.2020.126220.

37. Feitosa CEA, Cardoso RP, Brunatto SF. Development of a methodology for measuring the evolution of duplex stainlesssteel low-temperature plasma nitrided phases expansion using confocal laser scanning microscopy. Rev Bras Apl Vac. 2021;40(1):e0821. http://dx.doi.org/10.17563/rbav.v40.1194.

38. Rovani AC, Breganon R, Souza GS, Brunatto SF, Pintaúde G. Scratch resistance of low-temperature plasma nitrided and carburized martensitic stainless steel. Wear. 2017;376-377:70-6. http://dx.doi.org/10.1016/j.wear.2017.01.112.

39. Scheuer CJ, Cardoso RP, Brunatto SF. Sequential low-temperature plasma-assisted thermochemical treatments of the AISI 420 martensitic stainless steel. Surf Coat Tech. 2021;421:127459. http://dx.doi.org/10.1016/j.surfcoat.2021.127459.

40. Dong ZH, Zhang W, Kang HW, Xie YJ, Ebrahimnia M, Peng X. Surface hardening of laser melting deposited $12 \mathrm{CrNi} 2$ alloy steel by enhanced plasma carburizing via hollow cathode discharge. Surf Coat Tech. 2020;397:125976. http://dx.doi.org/10.1016/j. surfcoat.2020.125976.

41. Scheuer CJ, Cardoso CJ, Zanetti FI, Amaral T, Brunatto SF. Low-temperature plasma carburizing of AISI 420 martensitic stainless steel: influence of gas mixture and gas flow rate. Surf Coat Tech. 2012;206(24):5085-90. http://dx.doi.org/10.1016/j. surfcoat.2012.06.022.

42. Brunatto SF, Correa VS, Machado KD, Muzart JLR. Influence of pressure on the morphology and structure of surfaces sintered in pulsed DC annular hollow cathode discharge. Surf Coat Tech. 2018;344:402-9. http://dx.doi.org/10.1016/j.surfcoat.2018.02.090.

43. Mason RS, Pichilingi M. Sputtering in a glow discharge ion source-pressure dependence: theory and experiment. J Phys D Appl Phys. 1994;27(11):2363-71. http://dx.doi.org/10.1088/00223727/27/11/017

44. Mason RS, Allott RM. The theory of cathodic bombardment in a glow discharge by fast neutrals. J Phys D Appl Phys. 1994;27(11):2372-8. http://dx.doi.org/10.1088/0022-3727/27/11/018. 
45. Brunatto SF, Cardoso SF, Scheuer CJ. Martensitic stainless steel: direct current low-temperature plasma carburizing. In: Colás R, Totten GE, editors. Encyclopedia of iron, steel, and their alloys. New York: Taylor \& Francis; 2016. p. 2153-68. http://dx.doi.org/10.1081/E-EISA-120051667.

46. Bogaerts A, Neyts E, Gijbels R, Van der Mullen J. Gas discharge plasmas and their applications. Spectrochim Acta B At Spectrosc. 2002;57(4):609-58. http://dx.doi.org/10.1016/ S0584-8547(01)00406-2.

47. Booth M, Farrell T, Johnson RH. The theory and practice of plasma carburizing. Mater Des. 1984;5(3):139-48. http://dx.doi. org/10.1016/0261-3069(84)90083-9.

48. Davis WD, Vanderslice TA. Ion energies at the cathode of a glow discharge. Phys Rev. 1963;131(1):219-28. http://dx.doi. org/10.1103/PhysRev.131.219.

49. Chapman BN. Glow discharge processes: sputtering and plasma etching. New York: John Wiley \& Sons; 1980.

50. Brunatto SF. Plasma assisted parts' manufacturing: sintering and surface texturing - part II - influence of inter-cathode distance and gas pressure. J Braz Soc Mech Sci Eng. 2010;32(2):136-45. http://dx.doi.org/10.1590/S1678-58782010000200006.

51. Brunatto SF, Kühn I, Klein AN, Muzart JLR. Sintering iron using a hollow cathode discharge. Mater Sci Eng A. 2003;343(12):163-9. http://dx.doi.org/10.1016/S0921-5093(02)00383-0.

52. Edenhofer B. Physical and metallurgical aspects of ionnitriding - part II. Heat Treatment of Metals. 1974;2:59-67.

53. Oliveira RM, Ueda M, Silva LLG, Reuther H, Lepienski CM. Characteristics of austenitic stainless steel nitrided in a hybrid glow discharge plasma. Braz J Phys. 2009;39(3):554-8. http:// dx.doi.org/10.1590/S0103-97332009000500008.

54. Bonagani SK, Kain V, Naveen Kumar N, Donthula H. Effect of austenitization-cooling on microstructure and localized corrosion behavior of $13 \mathrm{Cr}$ martensitic stainless steel. J Mater Eng Perform. 2021;30(3):2291-9. http://dx.doi.org/10.1007/ s11665-021-05460-6.

55. Zhao Y, Liu W, Zhang T, Sun Z, Wang Y, Fan Y, et al. Assessment of the correlation between M23C6 precipitates and pitting corrosion resistance of $0 \mathrm{Cr} 13$ martensitic stainless steel. Corros Sci. 2021;189:109580. http://dx.doi.org/10.1016/j. corsci.2021.109580.

56. Zhao Y, Liu W, Fan Y, Zhang T, Dong B, Chen L, et al. Influence of microstructure on the corrosion behavior of super $13 \mathrm{Cr}$ martensitic stainless steel under heat treatment. Mater Charact. 2021;175:111066. http://dx.doi.org/10.1016/j. matchar.2021.111066.

57. Anjos AD, Scheuer CJ, Brunatto SF, Cardoso RP. Low-temperature plasma nitrocarburizing of the AISI 420 martensitic stainless steel: microstructure and process kinetics. Surf Coat Tech. 2015;275:51-7. http://dx.doi.org/10.1016/j.surfcoat.2015.03.039.

58. Thelning K-E. Steel and its heat treatment. 2nd ed. London: Butterworth \& Co.; 1975.

59. Brunatto SF, Kühn I, Muzart JLR. Surface modification of iron sintered in hollow cathode discharge using an external stainless steel cathode. J Phys D Appl Phys. 2005;38(13):2198-203. http://dx.doi.org/10.1088/0022-3727/38/13/018.

60. Brunatto SF, Muzart JLR. Influence of the gas mixture flow on the processing parameters of hollow cathode discharge iron sintering. J Phys D Appl Phys. 2007;40(13):3937-44. http:/ dx.doi.org/10.1088/0022-3727/40/13/005.

61. Araújo VB. Estudo das potencialidades do processo de cementação por plasma sem aquecimento auxiliar [thesis]. Florianópolis: Universidade Federal de Santa Catarina; 1999 [cited 2020 May 12]. Available from: https://repositorio.ufsc. br/xmlui/handle/123456789/80726

62. Liu R, Yan M. Characteristics of AISI 420 stainless steel modified by low-temperature plasma carburizing with gaseous acetone. Coatings. 2019;9(2):75. http://dx.doi.org/10.3390/ coatings 9020075 .

63. Gao F, Zong X, Tian L, Quan S. Microstructure and mechanical properties of low temperature carburizing layer on AISI 440C martensitic stainless steel. Mater Express. 2020;10(6):841. http://dx.doi.org/10.1166/mex.2020.1698.

64. Yin L, Ma X, Tang G, Fu Z, Yang S, Wang T, et al. Characterization of carburized $14 \mathrm{Cr} 14 \mathrm{Co} 13 \mathrm{Mo} 4$ stainless steel by low pressure carburizing. Surf Coat Tech. 2019;358:654-60. http://dx.doi. org/10.1016/j.surfcoat.2018.11.090.

65. Brunatto SF, Scheuer CJ, Boromei I, Martini C, Ceschini L, Cardoso RP. Martensite coarsening in low-temperature plasma carburizing. Surf Coat Tech. 2018;350:161-71. http://dx.doi. org/10.1016/j.surfcoat.2018.07.002.

66. Olzon-Dionysio M, Campos M, Kapp M, Souza S, Souza SD. Influences of plasma nitriding edge effect on properties of 316 L stainless steel. Surf Coat Tech. 2010;204(21-22):3623-8. http://dx.doi.org/10.1016/j.surfcoat.2010.04.034.

67. Shen H, Wang L. Mechanism and properties of plasma nitriding AISI 420 stainless steel at low temperature and anodic (ground) potential. Surf Coat Tech. 2020;403:126390. http://dx.doi. org/10.1016/j.surfcoat.2020.126390.

68. Alves C Jr, Araújo FO, Ribeiro KJB, Costa JAP, Sousa RRM, de Sousa RS. Use of cathodic cage in plasma nitriding. Surf Coat Tech. 2006;201(6):2450-4. http://dx.doi.org/10.1016/j. surfcoat.2006.04.014.

69. Kobashi K. Diamond films. Amsterdam: Elsevier Science; 2005. Chapter 10, Diamond nucleation; p. 121-53. http://dx.doi. org/10.1016/B978-008044723-0/50011-8. 